\title{
Eksistensi Batik Pecel (Sejarah, Makna Simbolis Dan Potensinya Sebagai Ikon Pariwisata Kota Madiun)
}

\author{
Bella Aulia Sahidah' ${ }^{1}$ dan Novi Triana Habsari ${ }^{2}$
}

${ }^{1}$ Alumni Program Studi Pendidikan Sejarah, FKIP, Universitas PGRI Madiun ${ }^{2}$ Dosen Program Studi Pendidikan Sejarah, FKIP, Universitas PGRI Madiun

\begin{abstract}
Abstrak
Penelitian ini bertujuan untuk mengetahui eksistensi, sejarah dan makna simbolis Batik Pecel sebagai ikon pariwisata Kota Madiun. Penelitian ini menggunakan pendekatan kualitatif dengan jenis deskriptif kualitatif. Teknik pengumpulan data menggunakan teknik observasi, wawancara, dan analisis dokumen. Validasi data menggunakan triangulasi sumber. Hasil penelitian diperoleh bahwa batik pecel Kota Madiun merupakan salah satu batik daerah Madiun diawali ibu walikota Madiun tahun 2009. Batik ini memiliki makna tiap motifnya. Saat ini terdapat 3 motifyang berkembang di Kota Madiun, yaitu 1). motif pecelan komplit berisi berbagai macam ornamen sajian nasi pecel, yang melambangkan persatuan dan kesatuan yang menimbulkan kedamaian sehingga indah untuk dipandang, 2). motif pecelan gunungan dengan motif hanya ornamen sajian kuliner nasi pecel terletak di dalam segitiga, dan digambarkan sebagai gunung sehingga dinamakan motif pecelan gunungan. Motif pecelan gunungan bermakna harapan pemerintah mengenai Kota Madiun yang semakin berkembang dan tetap menjadi nomor satu kebanggan masyarakat Kota Madiun, 3). Motif menggambarkan kebudayaan masyarakat Madiun dalam menyajikan dan mengkonsumsi nasi pecel. Terlihat dari motif sajian nasi pecel yang diletakkan di atas daun pisang yang diikat dengan batang lidi. Batik ini berpotensi untuk dijadikan ikon pariwisata, sebab menggambarkan kondisi sosial budaya Kota Madiun. Batik tersebut memiliki keunikan Karena saat ini belum ada batikyang menggambarkan sajian kuliner suatu daerah.
\end{abstract}

Kata Kunci: Eksistensi, Batik Pecel, Ikon Pariwisata

\section{Pendahuluan}

Pembangunan Nasional bertujuan untuk mewujudkan masyarakat adil dan makmur yang merata berdasarkan Pancasila dan Undang-Undang Dasar 1945. Untuk mewujudkan tujuan tersebut, maka pembangunan yang dilaksanakan oleh bangsa Indonesia adalah pembangunan di segala bidang. Pemberlakuan UU Nomor 32 Tahun 2004 tentang pemerintahan Daerah secara riil merupakan titik tolak yang sangat strategis bagi daerah untuk dapat menggali, mengembangkan dan mengelola aset-aset yang dimiliki serta memberdayakannya bagi pembangunan perekonomian daerah setempat. Oleh karena itu, pemerintah daerah perlu mencermati sektor-sektor strategis yang memiliki potensi kuat untuk menopang pembangunan di daerahnya, sehingga dapat meningkatkan Pendapatan Asli daerah (PAD).

Salah satu sektor yang mampu menyumbangkan PAD diperoleh dari sektor pariwisata. pembangunan pariwisata diselenggarakan melalui proses yang dinamis bersama dengan sektor yang lainnya menuju ke arah peningkatan kualitas dan kuantitas pelayanan yang lebih baik. Besarnya potensi bagi pengembangan pariwisata Indonesia sukses 
tidaknya pembangunan pariwisata pada saat ini sangat ditentukan oleh adanya dukungan serta partisipasi aktif dari seluruh lapisan masyarakat, baik pemerintah, swasta maupun masyarakat lainnya. Sektor pariwisata secara riil merupakan salah satu sektor strategis penggerak pembangunan perekonomian daerah, pengembagan wilayah, serta pemberdayaan masyarakat. Salah satu kota yang memiliki potensi dalam sektor pariwisata adalah Kota Madiun.

Untuk pengembangan pariwisata di Kota Madiun agar dapat dijadikan salah satu potensi yang ada guna meningkatkan perekonomian daerah, Kota Madiun mempunyai banyak lokasi objek wisata yang berhubungan dengan wisata. Baik itu wisata alam dan wisata bersejarah maupun wisata kuliner yang telah dikembangkan. Dari segi wisata alam salah satunya Kota Madiun memiliki Waduk Bening Widas berupa bendungan yang terletak di Dusun Petung Desa Padjajaran kecamatan Saradan jaraknya sekitar $40 \mathrm{Km}$ dari Kota Madiun.

Walaupun hanya berupa waduk, tempat ini biasa dijadikan tempat wisata bagi warga sekitar terutama di akhir pekan, karena di tempat ini para wisatawan dapat melakukan beberapa kegiatan berupa camping, atau memancing. Ditempat ini juga memiliki fasilitas yang dapat dinikmati pengunjung berupa kolam pancing, kios, taman bermain, rumah makan, penginapan, dermaga berserta perahunya yang dapat digunakan untuk berkeliling menikmati pemandangan wadung bening tersebut. Dari wisata kulinernya Madiun memiliki banyak sekali wisata kuliner yang dibanggakan oleh masyarakat Madiun yaitu Brem (sari tape yang di fermentasi), kerupuk puli (nasi dicampur puli kemudian dijemur), madumongso (terbuat dari ketan), dan nasi pecel yang merupakan kuliner utama yang bahkan setiap hari dan setiap saat dapat dijumpai keberadaannya. Kota dengan julukan kota GADIS (Perdagangan dan Industri) dengan berbagai jenis perdagangan dan industri yang ada di Kota Madiun.

Tabel 1. Jumlah perusahaan menurut kode industri kota Madiun tahun 2013

\begin{tabular}{|c|c|c|}
\hline \multicolumn{3}{|c|}{$\begin{array}{l}\text { Jumlah Perusahaan Menurut Kode Industri di Kota Madiun, } \\
\qquad 2013\end{array}$} \\
\hline Kode Industri & $\begin{array}{c}\text { Jumlah } \\
\text { Perusahaan }\end{array}$ & $\begin{array}{l}\text { Tenaga } \\
\text { Kerja }\end{array}$ \\
\hline 1 Makanan dan Minuman & 142 & 504 \\
\hline 2 Tembakau / Tobacco Industry & 2 & 108 \\
\hline 3 Pakaian Jadi & 3 & 28 \\
\hline 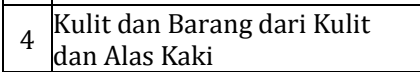 & 2 & 18 \\
\hline $5 \begin{array}{l}\begin{array}{l}\text { Kayu dan Barang dari Kayu } \\
\text { (Tidak Termasuk Furnitur) } \\
\text { dan Barang Anyaman }\end{array}\end{array}$ & 36 & 194 \\
\hline $6 \begin{array}{l}\text { Penerbitan, Percetakan, dan } \\
\text { Reproduksi Media Rekaman }\end{array}$ & 24 & 205 \\
\hline $7 \begin{array}{l}\text { Kimia dan Barang dari Bahan } \\
\text { Kimia }\end{array}$ & 2 & 40 \\
\hline $8 \begin{array}{l}\text { Karet dan Barang dari Karet } \\
\text { dan Barang dari Plastik }\end{array}$ & 5 & 31 \\
\hline 9 Barang Galian Bukan Logam & - & - \\
\hline \begin{tabular}{l|l}
10 & Logam Dasar \\
\end{tabular} & 9 & 131 \\
\hline $11 \begin{array}{l}\text { Barang dari Logam, Kecuali } \\
\text { Musin dan Peralatannya }\end{array}$ & 3 & 378 \\
\hline $12 \begin{array}{l}\text { Furnitur dan Pengolahan } \\
\text { Lainnya }\end{array}$ & 22 & 173 \\
\hline \begin{tabular}{l|l}
13 & Daur Ulang \\
\end{tabular} & - & - \\
\hline Jumlah & 250 & 1810 \\
\hline
\end{tabular}

Sumber: Disperindag Koperasi dan pariwisata Kota Madiun

Dari data tersebut bahwa tahun

2013 ada 250 industri di Kota Madiun yang didominasi oleh industri makanan dan minuman. Dengan data tabel tersebut dapat disimpulkan bahwa wisata kuliner Kota 
Madiun yang paling unggul dibandingkan dengan wisata alam maupun wisata bersejarah. Namun banyaknya potensi yang dimiliki Kota Madiun belum menjadikan hal tersebut sebagai penunjang kota wisata.

Letak Kota Madiun yang berada di Ujung Barat Propinsi Jawa Timur, dan berbatasan dengan wilayah Propinsi Jawa Tengah di Bagian Timur, menjadikan Kota Madiun sebagai salah satu Kota Persinggahan yang cukup diminati oleh para wisatawan yang ingin mengadakan perjalanan Ke beberapa wilayah di Propinsi Jawa Timur maupun Jawa Tengah. Di Kota ini, wisatawan, biasanya singgah di Madiun hanya untuk sekedar beristirahat sejenak menikmati suasana kota Madiun.

Selain terkenal sebagai kota GADIS, Kota Madiun juga terkenal sebagai kota pecel. Pecel yang merupakan kuliner khas Kota Madiun memiliki cita rasa yang berbeda sehingga menjadikan pecel sebagai kuliner terbaik kebanggaan masyarakat Kota Madiun. Oleh karena itu ibu Murni yang merupakan salah satu warga Kota Madiun terinspirasi untuk menuangkan pecel kedalam sebuah batik yang dinamakan sebagai batik pecelan.

Batik buatan lokal Kota Madiun sejak tahun 2011 ini memiliki motif pecelan yaitu berupa bahan-bahan yang terdapat dalam sajian khas Kota Madiun yaitu nasi pecel. Batik pecel merupakan produk yang berupaya untuk mengenalkan ikon atau ciri khas Kota Madiun kepada masyarakat luas terutama masyarakat dari luar Kota Madiun sehingga batik pecel merupakan salah satu potensi untuk meningkatkan eksistensi Kota Madiun yang dapat meningkatkan daya tarik wisata sehingga Kota Madiun bukan hanya sebagai kota transit tetapi Kota Madiun memiliki Ikon yang bernilai seni tinggi yang menggambarkan ciri khas daripada Kota Madiun itu sendiri.

Selain karena makna simbolis yang terdapat di motif batik pecelan, keindahan dari motif tersebut juga bisa di dapatkan dengan harga yang terjangkau. Sehingga batik pecel ini dapat dijadikan Ikon wisata dan buah tangan dari Kota Madiun. pecel dapat dimiliki oleh semua kalangan. Dan harapan ke depan semoga batik pecel ini mampu menarik wisatawan dan diminati oleh banyak masyarakat luas. Dengan batik pecel menjadi ikon Kota Madiun maka Madiun memiliki Ikon yang dapat menunjang diberbagai bidang misalnya saja di bidang perekonomian.

Perekonomian rakyat akan lebih baik, karena akan tercipta lapangan pekerjaan, dibidang sosial keterampilan masyarakat akan meningkat dalam hal membatik, hubungan kerjasama juga akan terjalin bukan hanya di kota Madiun dan Jawa Timur saja tetapi akan meluas ke berbagai kota-kota lainnya di Indonesia. Dan dengan kondisi seperti demikian maka Kota Madiun akan lebih baik karena selain anggaran pendapatan daerahnya 
bertambah, wisatawan yang berkunjung ke Kota Madiun juga meningkat. Sehingga dengan menarik dilakukan lebih lanjut mengenai batik pecel Kota Madiun.

\section{Tinjauan Pustaka}

\section{A. Eksistensi}

Menurut Fadhillah (2009: 29)

Eksistensi adalah cara manusia berada dalam dunia yang berbeda dengan beradanya benda-benda. Beradanya bendabenda menjadi bermakna karena manusia. Eksistensi berasal dari kata: eks (keluar) dan sistensi, yang diturunkan dari kata kerja sisto (berdiri, menempatkan). Menurut Kamus Besar Bahasa Indonesia Eksistensi adalah keberadaan, kehadiran yang mengandung unsur bertahan (2008: 357).

Dari beberapa pengertian tersebut disimpulkan bahwa eksistensi merupakan keberadaan yang mengandung unsur bertahan, namun dapat mengalami perkembangan dan kemunduran tergantung manusia itu sendiri, karena eksistensi dapat bermakna apabila manusia tersebut mengakui dan menempatkan keberadaan atau kehadiran akan sesuatu yang bernilai.

\section{B. Batik}

\section{Makna Batik}

Menurut Djoemena (dalam Hidayat, Fianto, dan Marzuki, 2015) menyatakan bahwa batik merupakan lukisan atau gambar pada mori (kain berasal dari serat kapas yaitu kain yang diputihkan dengan tenunan rapat, halus, lembut dan sedikit diberi kanji (Wahyuningsih, 2009: 3) yang dibuat dengan teknik canting, jadi orang yang melukis atau menggambar atau menulis pada mori memakai canting disebut membatik (bahasa Jawa: mbatik). Membatik menghasilkan batik atau batikan berupa macam-macam motif dan mempunyai sifat khusus yang dimiliki oleh batik itu sendiri.

Pendapat yang sama dikemukakan Musman (dalam Susanto, Bramantya, dan Santoso, 2011: 3) Batik berdasarkan etimologi dan terminologinya, merupakan rangkaian kata mbat dan tik. Mbat dalam bahasa Jawa diartikan ngembat atau melempar berkali-kali, sedangkan tik berasal dari kata titik. Jadi, membatik berarti melempar titik-titik berkali-kali pada kain. Ada juga yang berpendapat bahwa batik berasal dari gabungan dua kata bahasa Jawa amba yang bermakna menulis dan tik yang bermakna titik.

Batik merupakan kerajinan yang memiliki nilai seni tinggi dan telah menjadi bagian dari budaya Indonesia. Batik sebagai sebuah karya budaya memiliki nilai ekonomi yang tinggi, karena menjadi sumber hidup bagi para pengrajinnya, membuka lapangan usaha, menambah pendapatan daerah, dan mendukung kepariwisataan yang sangat potensial.

Dari beberapa pengertian batik di atas, dapat disimpulkan bahwa Batik adalah titik-titik yang digambar pada media kain yang lebar sehingga menghasilkan pola-pola yang indah. Batik memiliki arti kain 
bergambar yang pembuatannya secara khusus dengan menuliskan atau menerangkan malam pada kain, kemudian pengolahan diproses dengan cara tertentu.

\section{Jenis-jenis Batik}

Menurut Lisbijanto (2013: 10-12) memaparkan bahwa terdapat 3 jenis batik sesuai teknik pembuatan batik, yaitu:

a) Batik Tulis

Batik tulis dibuat secara manual menggunakan tangan dengan alat bantu canting untuk menerakan malam pada corak batik. Pembuatan batik tulis membutuhkan kesabaran dan ketelatenan tinggi karena setiap titik dalam motif berpengaruh pada hasil akhir. Motif yang dihasilkan dengan cara ini tidak akan sama persis. Kerumitan ini yang menyebabkan harga batik tulis sangat mahal. Jenis batik ini dipakai raja, pembesar keraton, dan bangsawan sebagai simbol kemewahan.

Menurut Nurainun, Heriyana dan Rasyimah (2008:127) semula batik tulis dibuat diatas bahan dengan warna putih yang terbuat dari kapas. Namun, saat ini batik juga dibuat diatas bahan lain, seperti sutera, polyester, rayon serta bahan sintetis lain. Salah satu kota yang menghasilkan batik tulis adalah Tuban Jawa Timur. Kota Tuban menghasilkan batik tulis yang dinamakan batik gedog.

b) Batik Cap

$$
\text { Batik cap dibuat dengan }
$$
menggunakan cap atau semacam stempel motif batik yang terbuat dari tembaga. Batik
Cap digunakan untuk menggantikan fungsi canting sehingga dapat mempersingkat waktu pembuatan. Motif batik cap dianggap kurang memiliki nilai seni karena semua motif sama persis. Harga batik cap cukup murah karena dapat dibuat secara masal.

Salah satu Kota yang memproduksi batik cap adalah Kota Pacitan yang memiliki batik khas Kota Pacitan bermotifkan kekayaan alam yang merupakan keindahan alam yang terdapat di Pacitan.

c) Batik Lukis

Batik lukis dibuat dengan melukiskan motif menggunakan malam pada kain putih. Pembuatan motif batik lukis tidak terpaku pada pakem motif batik yang ada. Motifnya dibuat sesuai dengan keinginan pelukis tersebut. Batik lukis ini mempunyai harga yang mahal karena tergolong batik yang eksklusif dan jumlah terbatas. Salah satu kota yang memproduksi batik lukis adalah Kabupaten Tulungagung yang memproduksi batik dengan cara melukis menggunakan tusuk gigi.

\section{Pecel}

\section{Pengertian Pecel}

Pengertian pecel adalah pecel/pe·cel/ $n$ makanan yang terdiri atas sayuran, seperti kacang panjang, bayam, taoge yang disiram dengan kuah sambal kacang dan sebagainya (dalam https://kbbi.web.id/pecel). Ada yang menyatakan bahwa pengertian pecel yaitu berasal dari kata Pecel (beberapa daerah melafalkannya pecal) adalah makanan yang 
menggunakan bumbu sambal kacang sebagai bahan utamanya yang dicampur dengan aneka jenis sayuran (dalam https://id.wikipedia.org/wiki/Pecel). Asal kata dan daerah pecel belum diketahui secara pasti, tetapi dalam bahasa Jawa, pecel dapat diartikan sebagai 'tumbuk' atau 'dihancurkan dengan cara ditumbuk.

Menurut beberapa pengertian diatas dapat disimpulkan bahwa makna pecel adalah kuliner yang memiliki komposisi dari berbagai macam bahan yang sederhana dan mudah didapatkan, bahan yang terdapat didalam pecel berupa sayuran yang dilengkapi dengan sambal kacang.

\section{Makna Pecel}

Pecel merupakan jenis kuliner yang legendaris dan merakyat, karena semua dari lapisan masyarakat tidak kesulitan untuk mengkonsumsi makanan ini. Pecel menggambarkan kepada kita bahwa masyarakat Indonesia merupakan masyarakat dengan tingkat keanekaragaman yang kompleks. Namun hal ini tidak menjadi kesulitan bagi masyarakat untuk melebur menjadi satu. Masyarakat dengan berbagai keanekaragaman tersebut dikenal dengan istilah masyarakat multikultural.

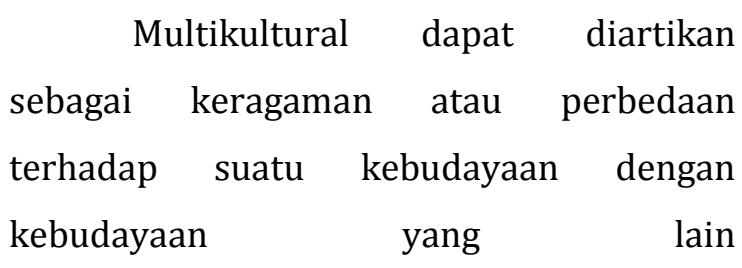

(http://11036nurfazrina.blogspot.co.id/201

2/06/sejarah-multikultural- multikultural.html.). Sehingga masyarakat multikultural diartikan sebagai sekelompok manusia yang tinggal dan hidup menetap di suatu tempat yang memiliki kebudayaan dan ciri khas tersendiri yang mampu membedakan antara satu masyarakat dengan masyarakat yang lain.

Setiap masyarakat akan menghasilkan kebudayaan masing-masing yang akan menjadi kekhasan bagi masyarakat tersebut. Terdapat 2 teori yang menjelaskan bahwa pecel merupakan kuliner yang multikultur, yaitu:

a) Teori melting pot

Adalah melebur berbagai unsur yang berbeda untuk menjadikan satu bentukan baru (http://11036nurfazrina.blogspot.co.id/ 2012/06/sejarahmultikultural-

multikultural.html). Gambarannya mungkin mirip bumbu pecel. Kacang, cabe, juga daun jeruk purut, garam, dan bahan-bahan lain dilebur jadi satu menjadi bumbu pecel, kemudian terbentuk gumpalan berwarna merah kehitaman atau kecokelatan.

Tidak terlihat lagi bentuk asli kacangnya. Juga sulit menemukan di mana garamnya, daun jeruk purutnya, atau cabenya. Bentuk asli seluruh bahan tadi telah dilebur (dengan cara dihancurkan) untuk menyusun bentukan baru berupa bumbu pecel. Konsep melting pot, jati diri setiap etnis atau suku dihilangkan. Tidak ada lagi yang 
namanya suku Sunda, Betawi, Timor, Papua, Dayak. Hanya ada satu suku besar bernama Indonesia. Masalahnya, bangsa Indonesia terdiri atas banyak suku yang budayanya sangat beragam. Menurut suatu suku, sebuah tindakan bisa jadi sebagai hal wajar, namun sudah masuk kategori tidak wajar bagi suku lain. Penolakan seperti itu adalah wajar. Ketika sebuah komunitas dipaksa berperilaku yang berbeda atau bahkan bertentangan dengan budayanya, kecenderungannya adalah menolak.

Itu yang terjadi ketika harus melebur bahan-bahan pembuat bumbu pecel. Bisa jadi ada kacang yang terlalu keras, sehingga tidak bisa dilebur. Ketika dipaksakan, sang kacang justru meloncat dari cobek untuk kemudian memisahkan diri menjadi "separatis" keluar dari bentukan baru bernama bumbu pecel. Apabila konsep melting pot seperti diterapkan dalam kehidupan berbangsa, bukan tidak mungkin etnis-etnis yang merasa dipaksa melebur lebih memilih keluar dan menjadi separatis.

b) Teori salad bowl

Adalah menjadikan negara layaknya mangkuk salad (http://rukinfirda.blogdetik.com/2013/ 02/14/halo-duniac). Isi beraneka ragam. Dicampur dalam satu mangkuk tanpa menghilangkan bentuk asli setiap bahan. Paprika tetap terlihat sebagai paprika. Kubis pun tetap terlihat sebagai kubis.
Jika ada jagung, tetap terlihat dan terasa sebagai jagung. Meski begitu, sebagai sebuah sajian, salad tetap enak disantap. Sama seperti pecel yang sajian bahanbahannya dicampur dalam satu mangkuk namun tetap seperti wujud aslinya.

Daun singkong tetap terlihat seperti daun singkong, kacang panjang tetap terlihat seperti kacang panjang, gantheng (toge) juga tetap memiliki bentuk yang sama, dan bahan-bahan yang terdapat didalam sajian nasi pecel lainnya. Namun meskipun seperti itu nasi pecel menjadi sebuah sajian yang dinikmati oleh semua masyarakat dari semua golongan. Gambaran seperti itu yang terjadi dalam sebuah bangsa yang terdiri atas berbagai suku atau etnis yang beragam.

Dari Jawa biarkan berkembang dan berperilaku sesuai budaya Jawanya. Yang dari Aceh beri keleluasaan berperilaku dan berbudaya sesuai etnisnya. Dan sebagainya. Istilah bangsa Indonesia hanya dressing dari salad bernama Indonesia. Dari Bali tetap terlihat sebagai orang Bali, yang dari Ambon tetap menunjukkan jati dirinya sebagai orang Ambon, dan sebagainya. Namun, mereka tetap merasa sebagai satu kelompok yang lebih besar, sebuah bangsa bernama Indonesia.

Sama persis salad dan pecel. Masingmasing bahan tetap terlihat bentuk aslinya, namun mereka terangkai dalam sebuah sajian yang satu bernama 
pecel/salad. Dari paparan tersebut dapat disimpulkan bahwa pecel bukan hanya sebagai kuliner yang banyak diminati, namun pecel memiliki makna yang berkaitan dengan multikultur yang berkenaan dengan bangsa Indonesia, yang merupakan salah satu Negara dengan jumlah suku, budaya, agama, dan etnis yang berbeda-beda.

Namun jika membaur menjadi satu akan menjadi sesuatu yang dapat dinikmati karena indah dipandang dan damai jika dirasakan. Sama seperti kuliner nasi pecel yang terdiri dari bahan yang berbeda-beda namun indah jika dilihat dan nikmat jika dirasakan.

\section{Makna Simbolis}

Simbol berasal dari bahasa Yunani yaitu yambolos yang berarti tanda atau diri yang memberikan sesuatu hal kepada seseorang. Dalam kamus umum bahasa Indonesia simbol atau lambang ialah sesuatu seperti tanda: lukisan, perkataan, kencana dan sebagainya, yang menyatakan suatu maksud tertentu, misalnya warna putih ialah lambang kesucian, gambar padi sebagai lambang kemakmuran atau berarti juga tanda pengenal yang tetap yang menyatakan sifat, keadaan, dan sebagainya misalnya tutup peci merupakan tanda pengenal tutup kepala nasional Indonesia (Satoto dalam Dwiyasmono, 2006: 2).

Cassier (dalam Bisri, 2005: 2) mengemukakan bahwa manusia adalah animal symbolicum, binatang yang mengenal simbol. Secara biologis manusia termasuk jenis binatang menyusui (mamalia), meskipun demikian manusia berbeda dengan binatang karena kemampuannya melakukan simbolisasi. Manusia adalah makhluk yang mampu menggunakan, mengembangkan, menciptakan, lambanglambang untuk berkomunikasi dengan sesamanya. Melalui lambang-lambang pula manusia menanggapi lingkungannya.

Dari beberapa pengertian tersebut dapat disimpulkan bahwa makna simbolis adalah tanda yang memiliki sebuah makna bertujuan untuk menyampaikan pesan kepada masyarakat luas. Dengan adanya makna simbolis akan mempermudah seseorang untuk memahami suatu nilai dari sebuah objek tertentu

\section{E. Ikon Pariwisata}

Sobur (dalam Hidayat, 2015: 3) menyatakan ikon adalah tanda yang mewakili sumber acuan melalui sebuah bentuk replikasi, simulasi, imitasi, atau persamaan. Menurut Pierce, Ikon adalah hubungan antara tanda dan objeknya atau acuan yang bersifat kemiripan. Disebutkan pula menurut Budiman (dalam Hidayat, 2015: 3) bahwa ikon adalah tanda yang memiliki kemiripan/similaritas dengan objeknya. Secara umum setiap daerah khususnya Jawa memiliki banyak Ikon daerah, salah satu diantaranya adalah batik yang telah menjadi ikon budaya Jawa. Secara umum di beberapa wilayah tertentu telah berkembang yang disebut batik 
tradisional, yaitu batik yang memiliki. Marzuki dkk (2015: 4) mengemukakan bahwa ciri khas dan spesifikasi setiap unsur tertentu sebagai sebuah karakter dan setiap daerah-daerah yang dirasa belum memiliki batik yang berciri khas daerahnya mulai berupaya untuk mencari dan memilah ikonikon tertentu untuk mendukung spesifikasi unsur-unsurnya agar mendapatkan sebuah simbol daerah dalam pembatikan.

Ada beberapa unsur daerah yang dapat diangkat menjadi simbol tertentu, yaitu: flora dan fauna, nilai sejarah daerah, geografik daerah, nilai budaya/kesenian daerah, dan simbol baru yang di inovasi (pengembangan dari stilisasi). Istilah pariwisata (tourism) baru muncul di masyarakat kira-kira abad ke-18, khususnya sesudah revolusi Industri di Inggris. Istilah pariwisata berasal dari dilaksanakan kegiatan wisata, yaitu aktivitas perubahan tempat tinggal sementara dari seseorang, di luar tempat tinggal sehari-hari dengan alasan apapun selain melakukan kegiatan yang bisa menghasilkan upah atau gaji (Muljadi, 2009: 7).

Pendapat senada juga dikemukakan Yoeti (1996: 118) bahwa suatu perjalanan yang dilakukan untuk sementara waktu, yang diselenggarakan dari suatu tempat ke tempat lain, dengan maksud bukan untuk berusaha atau mencari nafkah di tempat yang dikunjungi, tetapi semata-mata untuk menikmati perjalanan tersebut guna pertamasyaan dan rekreasi atau untuk memenuhi keinginan yang beraneka ragam. Menurut Sedarmayanti (2014: 55) mengemukakan pariwisata adalah berbagai macam kegiatan wisata yang didukung berbagai fasilitas serta layanan yang disediakan masyarakat, pengusaha, pemerintah, dan pemerintah daerah.

Pariwisata memberikan banyak pemasukan bagi daerah yang sadar akan potensinya terhadap sektor pariwisata. Ismayanti (dalam Hamid, 2016: 75) pariwisata adalah berbagai macam kegiatan wisata dan didukung fasilitas serta layanan yang disediakan masyarakat, pengusaha, pemerintah dan pemerintah daerah. Pariwisata menjadi industri penting dalam pembangunan di bidang ekonomi bagi pihak yang terkait dalam hal ini stakeholder antara lain pemerintah, pemilik industri, maupun masyarakat yang bersama-sama ikut serta dalam kegiatan pariwisata.

Dari pengertian tersebut dapat disimpulkan pengertian ikon pariwisata adalah tanda yang mewakili sumber acuan melalui sebuah bentuk replikasi, simulasi, imitasi, atau persamaan yang terdapat dalam kegiatan wisata yang disediakan oleh masyarakat, pengusaha, pemerintah dan pemerintah daerah suatu kota. Dengan adanya ikon pariwisata suatu daerah akan memiliki objek yang diunggulkan, sebab secara tidak langsung ikon pariwisata memiliki fungsi untuk menambah daya tarik wisata suatu objek. Menurut Peraturan Pemerintah Republik Indonesia Nomor 50 
Tahun 2011 Tentang Rencana Induk Pembangunan Kepariwisataan Nasional Ada 23 Jenis wisata yang di kembangkan di Indonesia guna menarik wisatawan, yaitu: Wisata Petualangan, Wisata Bahari, Wisata Agro, Wisata Kreatif, Wisata Kapal Pesiar, Wisata Kuliner, Wisata Budaya, Wisata Sejarah, Wisata Memorial (Ground Zero, World Trade Centre, Ground Zerolegian Bali, Merapi Pasca Letusan), Wisata Ekologi, Wisata Pendidikan, Wisata EkstrimMenantang Bahaya (Bercanda Dengan Hiu, Bercanda Dengan Buaya),

Wisata Massal, Wisata Pertemuan, Perjalanan Insentif, Konferensi Dan Pameran, Wisata Kesehatan, Wisata Alam, Wisata Religi, Wisata Budaya Kekinian, Wisata Desa, Wisata Luar Angkasa, Wisata Olahraga, Wisata Kota, Wisata Relawan. Dari jenis-jenis pariwisata tersebut maka dalam tulisan ini kategori jenis pariwisata adalah jenis wisata kreatif.

Sebab wisata kreatif memiliki kajian yang luas sesuai dengan batik pecelan khas Kota Madiun yang dapat di unggulkan sebagai produk wisata yang menarik wisatawan untuk berkunjung ke Kota Madiun, dan ikut serta memperluas pengetahuan mengenai batik pecel dan dapat langsung berpartisipasi dalam proses pembuatan batik pecelan. Terdapat dampak adanya pariwisata bagi masyarakat, sesuai pendapat dari Cohen (dalam Sedarmayanti, 2014: 9) yang mengelompokkan dampak sosial budaya pariwisata ke dalam sepuluh kelompok besar, yaitu:

1. Dampak terhadap keterkaitan dan keterlibatan masyarakat setempat dengan masyarakat luas, termasuk tingkat otonomi atau ketergantungannya.

Adanya pariwisata di kota maka masyarakatnya mengalami berbagai perubahan. Salah satunya sektor sosial. Kehidupan sosial masyarakat meluas. Hal ini sebab hubungan yang terjalin guna mempublikasikan potensi pariwisata di kota tersebut agar lebih menguntungkan.

2. Dampak hubungan interpersonal antara anggota masyarakat.

Pariwisata menyebabkan kerukunan hubungan yang erat dari sebelumnya. Hal ini bertujuan agar bisa menjalin kerjasama yang saling menguntungkan.

3. Dampak terhadap dasar organisasi/kelembagaan sosial.

Pariwisata mempengaruhi dasar oganisasi dan lembaga sosial karena adanya pariwisata maka organisasi maupun kelembagaan sosial mengambil peran dan ikut berpartisipasi dalam pengelolaan maupun administrasi pariwisata. Hal tersebut menyebabkan perubahan terhadap dasar orginasisasi sosial di daerah tersebut.

4. Dampak terhadap migrasi dari dan ke daerah pariwisata.

Pariwisata berpengaruh terhadap migrasi karena adanya situs pariwisata daerah akan mengalami peningkatan 
migrasi dan hal itu menyebabkan pemerintah menyediakan fasilitas yang berfungsi menampung wisatawan yang bermigrasi misalnya penginapan.

5. Dampak terhadap ritme kehidupan sosial masyarakat.

Pariwisata memiliki pengaruh besar terhadap kehidupan sosial masyarakat karena keberadaan situs pariwisata di suatu daerah maka akan mempengaruhi pola pikir yang secara tidak langsung akan mengubah segala aspek yang berkaitan dengan kehidupan sosial.

6. Dampak terhadap pola pembagian kerja.

Pariwisata akan dikelola dan dikembangkan masyarakat setempat. Hal tersebut menyebabkan dampak pada pola pembagian kerja masyarakat.

7. Dampak terhadap stratifikasi dan mobilitas sosial.

Dipengaruhi oleh pariwisata karena suatu daerah akan mengalami berbagai keuntungan yang menyebabkan masyarakat mengalami perubahan stratifikasi dan mobilitas.

8. Dampak terhadap distribusi pengaruh dan kekuasaan.

Dengan adanya pariwisata tersebut maka akan berdampak terhadap distribusi pengaruh dan kekuasan karena pemerintah akan terus menetapkan kebijakan-kebijakan yang berkaitan dengan situs pariwisata tersebut. Hal ini bertujuan untuk menunjang situs tersebut agar lebih baik lagi.
9. Dampak terhadap meningkatnya penyimpangan sosial.

Pariwisata dapat mempengaruhi meningkatnya penyimpangan sosial. Sebab alkulturasi budaya yang tidak seimbang karena kebudayaan asing terus berkembang dan kebudayaan lokal menghilang. Kebiasaan masyarakat lokal mulai mengarah pada dampak terhadap bidang kesenian dan adat istiadat.

10. Dampak terhadap bidang kesenian dan adat istiadat

Kesenian dan adat istiadat daerah setempat mengalami perubahan karena pengaruh kebudayaan asing dan berkembang. Pengaruhnya terlihat jika pengaruh tersebut berdampak terhadap kehidupan masyarakat sekitar.

Dari beberapa dampak pariwisata yang telah dijelaskan, terutama setelah munculnya batik pecel sebagai ikon pariwisata Kota Madiun. Namun demikian, dampak yang paling ditimbulkan dengan adanya batik pecel sebagai ikon pariwisata Kota Madiun adalah dampak terhadap keterkaitan dan keterlibatan antara masyarakat setempat dengan masyarakat yang lebih luas, termasuk tingkat otonomi atau ketergantungannya.

Hal ini dikarenakan bahwa masyarakat akan memasarkan produk melalui berbagai media baik online maupun offline. Sehingga masyarakat akan lebih meluas hubungannya karena keterkaitannya dengan pemasaran tersebut. 
Selanjutnya, diperlukan tata kelola destinasi pariwisata yang tepat bagi keberlanjutan destinasi pariwisata. Menurut Peraturan Menteri Pariwisata Nomor 14 Tahun 2016 Pariwisata berkelanjutan adalah pariwisata yang memperhitungkan dampak ekonomi, sosial dan lingkungan saat ini dan masa depan, memenuhi kebutuhan pengunjung, industri, lingkungan dan masyarakat setempat serta dapat diaplikasikan ke semua bentuk aktifitas wisata di semua jenis destinasi wisata, termasuk wisata masal dan berbagai jenis kegiatan wisata lainnya.

Disebutkan pula menurut Peraturan Menteri Pariwisata Nomor 14 Tahun 2016 mengenai cangkupan kriteria pengelolaan yaitu: Strategi Destinasi Berkelanjutan, Organisasi Manajemen Destinasi, Monitoring, Pengelolaan Pariwisata Musiman, Adaptasi terhadap Perubahan Iklim, Inventarisasi Aset dan Atraksi Pariwisata, Pengaturan Perencanaan, Akses untuk Semua, Akuisisi Properti, Kepuasan Pengunjung, Standar Keberlanjutan, Keselamatan dan Keamanan, Manajemen Krisis dan Kedaruratan, dan Promosi.

Berdasarkan kriteria pengelolaan yang dipaparkan tersebut dapat disimpulkan bahwa pemerintah sudah membuat kebijakan tata kelola destinasi pariwisata. Namun tidak jarang pihak pengelolaan destinasi pariwisata kurang memperhatikan pedoman peraturan pemerintah sehingga destinasi yang ada tidak terekspos secara eksternal. Salah satunya Kota Madiun yang masih kurang memperhatikan pedoman perarturan pemerintah tentang tata kelola destinasi pariwisata agar tetap berkelanjutan.

Oleh karena dengan adanya batik pecel sebagai ikon Kota Madiun berpotensi menjadi salah satu unggulan yang dapat dibanggakan kemudian di promosikan agar Madiun dapat menjadi salah satu referensi kota wisata yang ada di Indonesia.

\section{Metode Penelitian}

Lokasi penelitian ini dilaksanakan di kota Madiun tepatnya di Jalan Halmahera Nomor 14 Kelurahan Kartoharjo Kota Madiun. Pemelihan lokasi penelitian karena sentra industri batik terbesar di Madiun terdapat di lokasi tersebut yang bernama Galery Batik Murni. Penelitian ini menggunakan pendekatan kualitatif. Sukmadinata (2007: 94) mengemukakan penelitian kualitatif adalah penelitian yang ditujukan untuk memahami fenomena sosial dari sudut partisipan. Partisipan adalah orang yang diajak berwawancara, diobservasi, diminta memberikan data, pendapat, pemikiran, presepsinya.

Sumber data penelitian ini adalah sumber data Primer yang di peroleh dari sumber pertama yaitu Kelurahan Kartoharjo, pencipta batik pecel, pemilik galery batik murni, karyawan atau pegawai batik murni serta beberapa warga $\mathrm{Jl}$. Halmahera Nomor 14. Sedangkan sumber 
data sekunder dalam penelitian ini berupa sumber pustaka yang diambil dari dokumen, arsip Kelurahan Kartoharjo, dan galery batik murni yang merupakan galery batik pecel terbesar di kota Madiun.

$$
\text { Untuk pengumpulan data }
$$
menggunakan beberapa teknik, yaitu: 1). Observasi, 2). Wawancara dalam penelitian menggunakan semiterstuktur dimana peneliti menggunakan pedoman wawancara namun pihak yang diwawancara bebas memberikan pendapat serta mengeluarkan saran maupun ide yang berupa kritik. Beberapa informan yang digunakan adalah a). Kepada Dinas Kebudayaan, Pariwisata, Pemuda dan Olahraga Kota Madiun, dan b). Kepala Dinas Penanaman Modal, Pelayanan Terpadu Satu Pintu, Koperasi Dan Usaha Mikro Kota Madiun, dan Galery Batik Murni, 3). Analisis dokumen berupa profil, foto serta data statistik Kota Madiun.

Teknik analisis data dalam penelitian ini menggunakan analisis data model interaktif yang terdapat tiga komponen, yakni: Reduksi data, Penyajian data, dan penarikan kesimpulan (Miles dan Huberman dalam Satori dan Komariah, 2012: 218 ).

\section{Hasil Dan Pembahasan}

\section{A. Sejarah Batik Pecel Kota Madiun}

Batik pecel ini merupakan salah satu batik daerah di Kota Madiun. Berawal dari didapatkannya rekor muri tentang pesta kuliner nasi pecel yang diikuti oleh 2000 orang pada tahun 2009, serta keinginan masyarakat untuk memperkenalkan lebih luas mengenai potensi yang dimiliki Kota Madiun, maka muncul gagasan untuk menciptakan sebuah batik yang memiliki motif khas kuliner yang menjadi kebanggaan masyarakat Kota Madiun yaitu nasi pecel. Nasi pecel merupakan salah satu kuliner yang mudah didapat di Kota Madiun. Hal ini terbukti masih banyak di jumpai warung-warung yang menjual sajian nasi pecel ini. Maka pada tahun 2010 terinspirasi dari sajian kuliner nasi pecel, walikota Kota Madiun Bambang Irianto mencoba menggerakkan seluruh pembatik yang ada di Kota Madiun untuk menciptakan sebuah batik yang bermotifkan kuliner pecel dengan makanan khas Kota Madiun. Pemerintah terus mengadakan pelatihan untuk para pembatik di Kota Madiun agar terus mengembangkan batik yang bermotifkan pecelan.

Meski payung hukum dari batik pecel tersebut masih dalam proses HAKI, namun tidak menyurutkan niat masyarakat bahwa Madiun memiliki batik yang bermotifkan kekhasan dari Kota Madiun, salah satunya yaitu batik pecel. Keterlibatan masyarakat Kota Madiun untuk mengenalkan produk batik pecelan ini dapat dibuktikan dengan berbagai event festival batik yang dilakukan oleh pemerintah sebagai salah satu upaya pemerintah untuk mengenalkan batik pecelan secara luas kepada masyarakat. Selain itu pemerintah 
selalu mencoba memasarkan produk batik ini, melalui event yang dilakukan baik tingkat regional dan nasional. Upaya pemerintah dalam melestarikan dan mengembangkan batik pecel dibuktikan melalui pelatihan yang mewajibkan para pembatik untuk mengikutinnya. Hal ini bertujuan untuk menjadikan batik pecel semakin diakui keberadaannya, bukan hanya oleh masyarakat di Kota Madiun saja namun diharapkan diakui keberadaannya oleh masyarakat luas.

Tercatat tahun 2014 sebanyak 30 pembatik di Madiun mengikuti pelatihan yang diadakan oleh Dinas Penanaman Modal, Pelayanan Terpadu Satu Pintu, Koperasi Dan Usaha Mikro Kota Madiun yang bertujuan untuk menghimbau para pembatik agar mengikuti program yang telah di buat oleh pemerintah yaitu membuat batik yang menggambarkan kekhasan Kota Madiun. Menurut data yang di peroleh dari Dinas Penanaman Modal, Pelayanan Terpadu Satu Pintu, Koperasi dan Usaha Mikro Kota Madiun.

Usaha pemerintah dalam menggerakkan para pembatik yang ada di Kota Madiun cukup berhasil. Hal ini sebab hampir seluruh pembatik di Kota Madiun mengikuti pelatihan dan membuka usaha batik meskipun belum memiliki galeri (usaha mikro). Dari 30 pembatik yang ada di Kota Madiun hanya 1 yang memiliki galeri batik yang memang selalu ditunjuk pemerintah jika ada wisatawan berkunjung di Kota Madiun yaitu galeri batik murni yang terletak di Jalan Halmahera Nomor 14.

\section{B. Makna Simbolis Batik Pecel}

Makna simbolis adalah suatu pemikiran yang memiliki makna berupa penekanan pada simbol. Dalam batik pecel makna simbolis yang terkandung terdapat dalam tiap jenis batik yang dibuat. Ada 3 jenis batik motif pecelan yang berkembang di Madiun, yaitu:

1. Motif Pecelan Komplit

Motif batik pecelan komplit ini menggambarkan berbagai macam komposisi atau bahan-bahan yang terdapat dalam sajian nasi pecel. Sehingga motif batik pecelan komplit ini yang paling diminati dibandingkan produk batik motif pecel lainnya. Motif ini bercorak berbagai macam bahan-bahan dari sajian nasi pecel, seperti cabe, kacang panjang, daun pepaya, daun singkong, kembang kanthil, kecambah, asem dan kacang tanah sebagai bahan utama dalam pembuatan sambel pecel.

Hal ini dituangkan kedalam batik dengan tujuan menggambarkan kepada masyarakat luas bahwa Madiun memiliki keanekaragaman latar belakang budaya, ras, dll. Namun dengan adanya perbedaan tersebut jika di satukan akan menimbulkan keselarasan dan persatuan. Dapat di tarik kesimpulan bahwa motif pecelan komplit merupakan motif batik pecel yang menggambarkan secara detail mengenai bahan-bahan yang terdapat dalam sajian 
nasi pecel, misalnya saja sayuran dari berbagai macam bentuk yang melambangkan satu kesatuan perbedaan yang jika disatukan dapat menghasilkan sesuatu yang disukai oleh masyarakat luas.

2. Motif Pecelan Gunungan

Motif pecelan gunungan ini adalah jenis yang kedua setelah motif pecelan komplit. Dalam motif batik pecelan gunungan ini menggambarkan bahan-bahan dalam sajian nasi pecel sama seperti motif pecelan komplit, namun lebih berpola membentuk gunung dan setiap gunungan memiliki satu hingga dua ornamen yang di lukiskan dalam batik tersebut. hal ini dapat diartikan juga mengenai harapan pemerintah bahwa Madiun menjadi kota yang semakin gemilang.

Hal ini digambarkan dalam bentuk bahan-bahan nasi pecel yang dibentuk segitiga seperti gunung yang menjulang tinggi ke langit. Dapat ditarik kesimpulan bahwa motif pecelan gunungan merupakan salah satu jenis motif pecelan yang diproduksi oleh galeri batik murni. Dalam batik tersebut menggambarkan mengenai bahan-bahan nasi pecel yang sudah dipola membentuk segitiga yang dianggap sebagai kejayaan yang diharapkan oleh pemerintahan Kota Madiun.

3. Motif Pecelan Pincuk

Motif pecelan pincuk ini memberikan gambaran mengenai adat istiadat atau kebiasaan para pedagang nasi pecel dalam menyajikan kuliner nasi pecel yaitu di pincuk (menurut KBBI online pincuk dalam bahasa Indonesia berarti wadah dari daun pisang yang dilipat dan disemat dengan lidi sehingga membentuk lekukan). Terlihat dari motif yang dituliskan pada batik menggambarkan pecelan yang di sajikan diatas daun pisang.

Dapat ditarik kesimpulan bahwa motif pecelan pincuk merupakan motif yang menggambarkan kebiasaan warga Madiun menghidangkan kuliner nasi pecel yang lebih dikenal oleh masyarakat dengan sebutan pincuk.

\section{Potensi Batik Pecel Sebagai Ikon Pariwisata Kota Madiun}

Ikon pariwisata adalah tanda yang mewakili sumber acuan melalui sebuah bentuk replikasi, simulasi, imitasi, atau persamaan yang terdapat dalam kegiatan wisata yang disediakan masyarakat, pengusaha, pemerintah dan pemerintah daerah kota. Dengan adanya ikon pariwisata suatu daerah akan memiliki objek yang diunggulkan, karena secara tidak langsung ikon pariwisata memiliki fungsi untuk menambah daya tarik wisata suatu objek.

Hal ini sesuai dengan pernyataan Marzuki dkk (2015: 4) yang mengemukakan bahwa ciri khas dan spesifikasi setiap unsur tertentu sebagai sebuah karakter dan setiap daerah yang dirasa belum memiliki batik yang berciri khas daerahnya mulai berupaya untuk mencari dan memilah ikon-ikon tertentu untuk mendukung spesifikasi unsur-unsurnya agar mendapatkan sebuah 
simbol daerah dalam pembatikan. Ada beberapa unsur daerah yang dapat diangkat menjadi simbol tertentu, antara lain:

1. Flora dan fauna

2. Nilai sejarah daerah

3. Geografik daerah

4. Nilai budaya/kesenian daerah

5. Simbol-simbol baru yang diinovasi

Dari pernyataan di atas bahwa batik pecel berpotensi untuk dijadikan ikon pariwisata Kota Madiun, karena batik pecel tersebut masuk kedalam unsur-unsur daerah yang layak jika dijadikan sebuah simbol daerah karena batik pecel memiliki unsur flora dan fauna serta nilai budaya dan kesenian daerah. Pernyataan ini juga diperkuat dari beberapa aspek yang ada, baik berkaitan dengan hasil wawancara, foto, dan hasil data primer maupun sekunder lainnya yang sudah didapatkan.

\section{Penutup}

\section{Simpulan}

Batik Pecel merupakan batik yang melambangkan ciri khas dari kuliner khas Kota Madiun yaitu nasi pecel. Batik ini mulai tercipta pada tahun 2011 diawali oleh festival kuliner nasi pecel yang mendapat gelar muri, sehingga Bambang Irianto (Walikota Kota Madiun) mempunyai gagasan untuk menciptakan suatu karya bertemakan nasi pecel. Sehingga pemerintah mulai diperintahkan untuk mengumpulkan, berdiskusi, dan memberikan pelatihan kepada para pembatik di Madiun. Saat ini di Madiun batik pecel memiliki 3 motif yaitu motif pecelan komplit, motif pecelan gunungan, motif pecelan pincuk. Yang masing-masing motif melambangkan bahan-bahan dari sajian kuliner nasi pecel namun dari ketiga jenis motif batik pecel yang ada motif batik pecelan yang paling digemari oleh pembeli.

Hal ini dikarenakan motif pecelan komplit ini menggambarkan ornamenornamen yang terperinci mulai dari bahan sayur yang digunakan dalam sajian nasi pecel seperti daun singkong, kacang panjang, kecambah, daun kemangi, kembang kanthil. Hingga bahan untuk membuat sambel pecel seperti cabai, kacang tanah, dan asem. Makna simbolis yang terkandung dari tiap-tiap motif batik pecel berkaitan dengan keberagaman karakter tiap masyarakat namun jika bersatu dan saling bahu-membahu maka akan timbul keselarasan atau kesatuan yang hakiki.

Hal tersebut digambarkan dalam motif pecelan komplit dan gunungan yang mencoba mengilustrasikan perbedaan karakter dari setiap bahan-bahan sajian nasi pecel yang dipadukan menjadi satu kesatuan yang menarik. Sedangkan motif dari pecelan pincuk menggambarkan kebiasaan masyarakat Kota Madiun dalam cara menyajikan kuliner nasi pecel tersebut yaitu dengan menyajikan kuliner nasi pecel menggunakan daun pisang sebagai alas makan. Makna yang terdapat di dalam batik pecel dirasa berpotensi untuk dijadikan 
sebagai ikon pariwisata Kota Madiun. Karena batik pecel Kota Madiun memiliki daya tarik tersendiri jika dibandingkan dengan batik daerah lainnya. Selain di tinjau dari makna simbolisnya batik ini memiliki keunikan yang berbeda karena batik ini bermotifkan makanan yang sampai saat ini tidak ada daerah lain yang memiliki batik bermotifkan seperti batik pecel tersebut.

Dengan begitu batik pecel dirasa berpontensi besar jika di jadikan ikon pariwisata yang nantinya akan menambah daya tarik Kota Madiun serta menambah jumlah wisatawan yang berkunjung di Kota Madiun. Keberadaan batik pecel ini juga mulai di akui oleh masyarakat. Pemerintah terus berupaya untuk memasarkan dan mengenalkan produk batik pecel ini kepada masyarakat luas terbukti pemerintah selalu membawa saat bertugas di luar kota dan menjadikan batik pecel ini sebagai souvenir jika ada tamu luar kota yang berkunjung di kedinasan Kota Madiun.

Pemerintah terus berupaya untuk melakukan pelatihan kepada para pembatik di Madiun agar selalu berkarya dan berinovasi agar tercipta lebih banyak lagi motif batik pecel yang lainnya. Sehingga harapan mengenai keberlangsungan dari keberadaan batik pecel ini sangat potensial.

\section{Daftar Pustaka}

Bisri, M.H. 2005. Makna Simbolis Komposisi Budaya Lemah Putih. Surakarta. Harmonia Jurnal Pengetahuan dan Pemikiran Seni. VI (2) 1-2. Diunduh pada: $21 \quad$ Maret 2017/www.portalgaruda.org

Departemen Pendidikan Nasional. 2008. Kamus Besar Bahasa Indonesia Pusat Bahasa. Jakarta: PT. Gramedia Pustaka Utama

Dwiyasmono. 2006. Simbolisme Tari Lambangsih dalam Upacara Perkawinan Adat Jawa Surakarta. Harmonia Jurnal Pengetahuan dan Pemikiran Seni. VII (2) 1-2. Diunduh pada: $21 \quad$ Maret 2017/www.portalgaruda.org

Fadhillah. 2009. Hakikat Hidup Manusia dalam Ruang dan Waktu Menurut Filsafat Eksistensialisme Heidegger. Jurnal Madani. Edisi II 29. Diunduh pada: $29 \quad$ Maret 2017.www.portalgaruda.org

Firda, R. 2013. Salad Bowl Atau Melting Pod. (Online). Diunduh pada: 24 Agustus 2017

http://rukinfirda.blogdetik.com/201 3/02/14/halo-dunia

J. Mulyadi. A. 2010. Kepariwisataan dan Perjalanan. Jakarta: Rajawali Press

Lisbijanto, H. 2013. Batik. Yogyakarta: Graha Ilmu

Marzuqi, A., Fianto, A.Y.A., Hidayat, W. 2015. Penciptaan Motif Batik Sebagai Ikon Kabupaten Lumajang. Jurnal Desain Komunikasi Visual. 4 (1) 1-4. Diunduh pada: 18 Maret 2017/ http://download.portalgaruda.org/a rticle.php?article $=297901 \& \mathrm{val}=549$ $6 \&$ title $=$ PENCIPTAAN $\% 20$ MOTIF\%2 0BATIK\%20SEBAGAI\%20IKON\%20 KABUPATEN\%20LUMAJANG

Nurainun., Heriyana., Rasyimah. 2008. Analisis Industri Batik di Indonesia. Jurnal Fokus Ekonomi (FE). 7(03) 124-129. Diunduh pada: 30 Maret 2017/ http://portalgaruda.org

Nurfazrina. 2012. Multikultur Di Indonesia.(Online) diunduh pada: 24 Agustus 2017. http://11036nurfazrina.blogspot.co. 
id/2012/06/sejarah-multikulturalmultikultural.html

Peraturan Menteri Pariwisata Republik Indonesia No. 14 Th. 2016. Tentang Pedoman Destinasi Pariwisata Berkelanjutan.

Peraturan Pemerintah Republik Indonesia No. 50 Th. 2011. Tentang Rencana Induk Pembangunan Kepariwisataan Nasional.

Santoso, F.L., Bramantya., Sutanto, R.P. 2011. Perancangan Buku Tentang Batik Mojokerto. Diunduh pada: 18 Maret 2017/http://download.portalgarud a.org/article.php?article $=194493 \& \mathrm{v}$ al=6515\&title=Perancangan $\% 20$ Buk u\%20Tentang\%20Batik\%20Mojoke rto

Satori, D., Komariah, A. 2012. Metodologi Penelitian Kualitatif. Bandung: Alfabeta

Sedarmayanti. 2014. Membangun dan Mengembangkan Kebudayaan dan Industri Pariwisata (Bunga Rampai Tulisan Pariwisata). Bandung: PT. Rafika Aditama

Sukmadinata, N.S. 2007. Metode Penelitian Pendidikan. Bandung: PT. Remaja Rosdakarya

Wahyuningsih, S.E. 2009. Pengaruh Suhu pada Proses Pembuatan terhadap Daya Susut Kain Batik dari Serat Kapas. Jurnal Kompetensi Tekhnik.1 (1). Diunduh pada: 6 April 2017/www.portalgaruda.org

Yoeti, O.A. 1996. Pengantar Ilmu Pariwisata. Bandung: Angkasa 